\title{
Genomic organization of duplicated short wave- sensitive and long wave-sensitive opsin genes in the green swordtail, Xiphophorus helleri
}

\author{
Corey T Watson' ${ }^{1}$ Krzysztof P Lubieniecki ${ }^{2}$, Ellis Loew ${ }^{3}$, William S Davidson², Felix Breden ${ }^{1 *}$
}

\begin{abstract}
Background: Long wave-sensitive (LWS) opsin genes have undergone multiple lineage-specific duplication events throughout the evolution of teleost fishes. LWS repertoire expansions in live-bearing fishes (family Poeciliidae) have equipped multiple species in this family with up to four LWS genes. Given that color vision, especially attraction to orange male coloration, is important to mate choice within poeciliids, LWS opsins have been proposed as candidate genes driving sexual selection in this family. To date the genomic organization of these genes has not been described in the family Poeciliidae, and little is known about the mechanisms regulating the expression of LWS opsins in any teleost.

Results: Two BAC clones containing the complete genomic repertoire of LWS opsin genes in the green swordtail fish, Xiphophorus helleri, were identified and sequenced. Three of the four LWS loci identified here were linked in a tandem array downstream of two tightly linked short wave-sensitive 2 (SWS2) opsin genes. The fourth LWS opsin gene, containing only a single intron, was not linked to the other three and is the product of a retrotransposition event. Genomic and phylogenetic results demonstrate that the LWS genes described here share a common evolutionary origin with those previously characterized in other poeciliids. Using qualitative RT-PCR and MSP we showed that each of the LWS and SWS2 opsins, as well as three other cone opsin genes and a single rod opsin gene, were expressed in the eyes of adult female and male $X$. helleri, contributing to six separate classes of adult retinal cone and rod cells with average $\lambda_{\max }$ values of 365 nm, 405 nm, 459 nm, 499 nm, $534 \mathrm{~nm}$ and $568 \mathrm{~nm}$. Comparative genomic analysis identified two candidate teleost opsin regulatory regions containing putative CRX binding sites and hormone response elements in upstream sequences of LWS gene regions of seven teleost species, including $X$. helleri.

Conclusions: We report the first complete genomic description of LWS and SWS2 genes in poeciliids. These data will serve as a reference for future work seeking to understand the relationship between LWS opsin genomic organization, gene expression, gene family evolution, sexual selection and speciation in this fish family.
\end{abstract}

\section{Background}

In order to link the fields of evolutionary genetics and behavioral ecology it is critical to understand the influences of genes on behavior [1]. This is especially important for understanding the processes of sexual selection and speciation $[2,3]$. Opsins are unique among genes known to influence behavior in that it is possible to make explicit mechanistic links between polymorphisms at the amino acid level, wavelength sensitivity at the

\footnotetext{
* Correspondence: breden@sfu.ca
'Department of Biological Sciences, Simon Fraser University, Burnaby, BC,

* Correspondence: breden@sfu.ca
${ }^{1}$ Department of Biological Sciences, Simon Fraser University, Burnaby, BC, Canada
}

receptor level, and phenotypic variation at the behavioral level [4]. Opsin genes have recently received a great deal of attention for their roles in mate choice, population divergence and speciation in African cichlids [reviewed in [5]], and have also been posited as candidate genes influencing behavior and sexual selection in the guppy and related species [6-8]. This is not surprising given that variation in opsin genes has facilitated the evolution of color vision across vertebrates $[9,10]$.

Vertebrate opsins make up an intermediate-sized gene family that code for a diverse group of $G$ proteincoupled receptors that initiate light absorbance and 
phototransduction through their interaction with one of two vitamin-A derived chromophore pigments [9]. The type of chromophore used as well as changes at key amino acid sites in the opsin protein are known to contribute to differences in the wavelength of light that is maximally absorbed $\left(\lambda_{\max }\right)$ [9]. Cone opsins, which are expressed in cone photoreceptor cells of the retina and responsible for mediating photopic vision, are comprised of four classes able to absorb light at different wavelengths across the spectrum. These are short wave-sensitive opsins (SWS1: ultraviolet to blue, and SWS2: violet to blue), medium to long wave-sensitive opsins ( $M W S$ or LWS: green to red), and rhodopsin-like opsins ( $R H 2$ : blue to green), all of which were present in the most recent common vertebrate ancestor. The number of functional opsin classes observed in extant vertebrates varies from species to species, contributing to interspecific variation in visual potential $[9,10]$.

In fishes, the evolution of color vision has been directed by opsin gene duplication and diversification, pseudogenization and differential gene expression [11]. This has allowed many species to evolve opsin repertoires and accompanying visual systems that best exploit the photic environments in which they live [12-14]. Furthermore, it is well established in many species that color vision plays a direct role in mate choice and sexual selection [15-18].

Fish in the family Poeciliidae, which includes the guppy and close relatives (Poecilia spp.), as well as swordtails and platyfishes (Xiphophorus spp.), are long standing models for the study of sexual selection, as both male secondary sexual characteristics and female mate choice are highly variable traits within the group [19-23]. In Poecilia, and less so in Xiphophorus, male coloration is known to affect female mate choice, although this is perhaps best understood in guppies where females show consistent preferences for males with orange and red color spots [15,24-26]. Furthermore, guppy female preference is known to differ between individuals within and across populations [27-29]. Using microspectrophotometry (MSP), Archer et al. [30] and Archer and Lythgoe [31] provided early mechanistic evidence for variation in guppy visual systems, indentifying expansions in the long wave-sensitive visual capacity of guppies, as well as variation between individuals in the number of long wave visual pigments observed in the retina. Interestingly, molecular data suggest that Xiphophorus and Poecilia species have expanded their $L W S$ opsin repertoires through gene duplication [6-8] corroborating this expansion in long wavelength sensitivity suggested by MSP. Within these poeciliid species, opsin duplication and diversification appears to be highest in Poecilia species, which have at least four different $L W S$ gene subtypes, compared to that of Xiphophorus pygmaeus, the only Xiphophorus species so far investigated with regard to LWS repertoire, which appears to possess only three [8].

Despite recent molecular work in poeciliids, no complete $L W S$ genomic repertoire has been described in any of these species. Obtaining a full description of $L W S$ opsins at the genomic level, including genomic organization, total gene copy number and intergenic sequences, will be an important step in elucidating the role that these genes have played in the evolution of this family, whether through gene duplication and divergence, or through differences in gene expression. To date, the genomic organization of cone opsins has been fully characterized in two other teleosts: the zerbrafish, Danio rerio [32], and medaka, Oryzias latipes [33]. Two LWS copies have been identified in each species [32,33]. Genomic data for $L W S$ loci are also available in the Ensembl release 56 [34] for Gasterosteus aculeatus (stickleback), Tetraodon nigroviridis (Tetraodon) and Takifugu rubripes (fugu), each of which possesses only a single $L W S$ gene. Additionally, the LWS genes are linked to at least a single SWS2 opsin gene in all five of the teleost species mentioned above [32-34]. The genomic organization of $L W S$ opsins has also been described in mammals and has contributed a great deal to the understanding of their evolution and function [35-38]. In humans, the characterization of MWS/LWS opsin gene organization has enabled the identification of regulatory regions essential for the proper expression of these genes and has been vital to the discovery of associations between opsin mutations and human color vision abnormalities [39-42].

In this study we screened bacterial artificial chromosome (BAC) libraries to characterize the genomic organization of $L W S$ and SWS2 opsins in the green swordtail, Xiphophorus helleri, which represents the first complete description of these genes in a member of the family Poeciliidae. We also characterized the spectral sensitivity of adult male and female retinae from this species with MSP and assessed the expression of opsin subtypes by PCR screening of whole eye total RNA. Additionally, using opsin intergenic sequences and cross-species comparisons to other teleosts, we identified potential distal gene regulatory elements including a tentative teleost LWS opsin Locus Control Region (LCR), analogous to LCRs previously described for mammalian and other teleost opsin loci.

\section{Methods}

\section{BAC Library screening}

For this study we used the $X$. helleri Bacterial Artificial Chromosome (BAC) library, VMRC27, previously constructed from $12 \mathrm{X}$. helleri males of the Rio Sarabia strain, representing a12-fold genome coverage [43]. Filters and 
BAC clones from this library were obtained from the Children's Hospital of Oakland Research Institute (CHORI; Oakland, CA, USA). Using LWS gene sequences from Poecilia reticulata [8], a 60-mer $L W S$ opsin specific probe (lwsprobe: ACAGCAAAGTTCAAGAAACTTCGTCATCCTCTCAACTGGATCTTGGTCAACCTTGCCATT) was designed from a portion of exon 2 exhibiting high sequence similarity between LWS subtypes $(100 \%$ sequence identity-S180, $A 180$ and $P 180$ subtypes; $91 \%$ sequence identity-S180r subtype). Both the $L W S$ opsin probe and overgo probe (designed to hybridize to filter 'anchor spots' for filter orientation) were end-labelled using ${ }^{32} \mathrm{P}$-ATP and T4 Polynucleotide Kinase (Invitrogen $^{\circ}$ ). BAC filter screening was conducted as described by Johnstone et al. [44]. Briefly, filter hybridization was carried out overnight at $65^{\circ} \mathrm{C}$ in $5 \times \mathrm{SSC}, 5 \times$ Denhardt's solution, and $0.5 \%$ SDS. Filters were subsequently washed three times for 60 minutes at $50^{\circ} \mathrm{C}$ in $1 \times \mathrm{SSC}$ and $0.1 \%$ SDS solution. Hybridized filters were visualized using a Storm 860 phosphoimager (Molecular Dynamics ${ }^{\circ}$ ).

\section{BAC clone characterization and sequencing}

The presence of a $L W S$ opsin in the BAC clones was confirmed by PCR using $L W S$ specific primers (see Additional file 1). BAC shotgun libraries were constructed as described by Johnstone et al. [44]. DNA was isolated from BAC clones shown by PCR to possess LWS and SWS2 loci (VMRC27-80H16, VMRC27186P13) using a QIAGEN Large-Construct kit. Following isolation the BAC DNA was sonicated, end-repaired, and size selected to $2-5 \mathrm{~kb}$ by gel electrophoresis and extracted using a QIAQuick gel purification kit (QIA$\mathrm{GEN}^{\circ}$ ). Size selected BAC DNA was ligated into Sma I digested, alkaline phosphatase treated pUC19 and used to transform XL1-Blue Supercompetent E. coli cells $\left(\right.$ Stratagene $\left.{ }^{\circ}\right) .1,152$ hybrid recombinant clones from the VMRC27-186P13 BAC shotgun library and 1,536 clones from the VMRC27-80H16 BAC shotgun library were sequenced bidirectionally (approximately $1000 \mathrm{bp}$ per clone), providing approximately $7 \times$ and $10 \times$ BAC clone coverage, based on the previously reported average BAC clone insert size of $160 \mathrm{~kb}$ [43]. BAC fingerprint contig data [45], and BAC shotgun library sequences were generated at the Michael Smith Genome Sciences Centre (Vancouver, BC, Canada).

\section{BAC sequence assembly and annotation}

Sequences from shotgun libraries were assembled and viewed using the Phred/Phrap and Consed packages [46-48]. The GRASP Annotation Pipeline [49-58] was used for gene annotation (see Additional File 1 for more details). $L W S$ nomenclature used for this study was adopted from Ward et al. [8]. LWS subtypes were differentiated by their "five-site" haplotypes [59], and each named for the amino acid found at the codon position representing the human " 180 " site. Codon position " 180 " is one of five key amino acid sites previously shown to contribute to shifts in spectral sensitivity of $M W S / L W S$ opsin proteins in vertebrates [59]. In the case of the $L W S$ subtypes reported here, "S" denotes a Serine, and "P" denotes a Proline at site "180". Names assigned to all other genes, including SWS2 opsins, were based on the top BLASTn results and sequence similarity to genes previously reported in other teleost species. SeqManPro (Lasergene 8.0, DNASTAR) was also used for sequence alignments containing BAC assembly consensus sequences and predicted gene sequences.

\section{RNA extraction and qualitative RT-PCR}

One male and one female $X$. helleri from the Rio Sarabia strain obtained from the Xiphophorus Genetic Stock Center (San Marcos, TX, USA) were euthanized in $\mathrm{NaHCO}_{3}$ buffered Tricaine Methanesulfonate (MS-222). The eyes were removed and total RNA was isolated from male and female specimens separately using the PureLink $^{\text {Th }}$ Micro-to-Midi Total RNA Purification kit (Invitrogen ${ }^{\circ}$ ). Purified RNA was treated with DNase I as per manufacturer's specifications (Fermentas ${ }^{\circ}$ ), and firststrand cDNA synthesis was carried out using 0.2 ug of DNase I-treated total RNA, Oligo dT and SuperScript ${ }^{\mathrm{tu}}$ II Reverse Transcriptase (Invitrogen ${ }^{\circ}$ ). Using locus specific primers, female and male whole eye cDNA was screened by PCR for the presence or absence of transcripts representing opsin subtypes, as well as the gephyrin gene (GPHN; explained below). Gene PCR fragments were either sequenced directly after PCR purification or cloned and sequenced (see Additional File 1 for PCR primers). A two round, nested PCR approach was utilized to amplify products for $S W S 2 A, R H 2-2$ and $S W S 1$ opsins. In the case of $S W S 2 A$ no visible product was produced in the first round, and amplification required a second round of PCR with internal primers. Visible products for both $R H 2-2$ and SWS1 opsins were produced in first round PCRs, but internal primers were used in a second round to increase locus specificity for direct sequencing of PCR products. In all $2^{\text {nd }}$ round PCR reactions 1:10 dilutions of the $1^{\text {st }}$ round PCR products were used. Cloning of PCR products was carried out using a TOPO TA Cloning ${ }^{\circ}$ kit with $\mathrm{pCR}^{\circ} 2.1$ $\mathrm{TOPO}^{\circ}$ vector and One Shot ${ }^{\circ}$ chemically competent TOP10 E. coli cells (Invitrogen ${ }^{\circ}$ ), and purified using a QIAprep ${ }^{\circ}$ Miniprep kit $\left(\mathrm{QIAGEN}^{\circ}\right)$. PCR products and clones were sequenced at Molecular Cloning Laboratories (MCLAB; San Francisco, CA, USA).

\section{Microspectrophotometry}

MSP was conducted following standard methodology, as described in Loew [60]. Two male and two female 
$X$. helleri individuals (Rio Sarabia strain) were darkadapted overnight before being euthanized in $\mathrm{NaHCO}_{3}-$ buffered MS-222. All procedures were carried out in a darkroom with minimal infrared illumination to prevent bleaching of the photoreceptor cells. Retinas were dissected from the eyes of each fish and placed on a glass slide in a drop of phosphate buffer $(\mathrm{pH} 7.2$ plus $6.0 \%$ sucrose) where they were macerated using two razor blades to free the photoreceptor cells and make them accessible for spectrographic measurement. Using a computer-controlled single beam instrument with a $100 \mathrm{~W}$ tungsten-halogen lamp, a $40 \times$ mirror objective lens as the condenser, and a $100 \times$ LOMO lens as the objective, individual photoreceptor cell outer segments were scanned from 750 to $350 \mathrm{~nm}$ and back at $1.0 \mathrm{~nm}$ intervals with odd $\mathrm{nm}$ scanned on the downward pass and even $\mathrm{nm}$ on the return pass. The selection criteria used for data inclusion into the $\lambda_{\max }$ analysis pool were the same as those used by Loew [60]. Each acceptable spectrum was smoothed prior to normalization using a digital filter routine ("smooft")[61]. For curves meeting the selection criteria, the $\lambda_{\max }$ (the wavelength at maximum absorbance for a template-derived visual pigment best fitting the experimental data) of the smoothed, normalized (using $\mathrm{X}_{\max }$ ) visual pigment absorbance spectrum was obtained using the method of Mansfield as presented by MacNichol [62]. The templates used were those of Lipetz and Cronin [63]. A template curve generated using the calculated $\lambda_{\max }$ was overlaid on the raw, unsmoothed data and visually examined for fit.

\section{Phylogenetic analyses}

$L W S$ and $S W S 2$ opsin coding sequences were obtained from GenBank. LWS and SWS2 sequences were aligned separately using ClustalW [64] within software package eBioX1.5.1 [65]. Phylogenetic analyses were conducted using PAUP* 4.0 [66]. Trees were reconstructed using Maximum Parsimony (MP) and Neighbor Joining (NJ) methods. Reconstruction of the LWS opsin NJ tree employed the General time reversible (GTR) model (with Rate Heterogeneity, alpha $=0.916$; Proportion of Invariant Sites $=0.332$ ). Likewise the GTR model (with Rate Heterogeneity, alpha $=0.505$ ) was used to construct the SWS2 opsin NJ phylogeny. Best-fit models were chosen using PhyML within the program TOPALi v2 [67]. Missing data were considered using the Pair-wise-Deletion option in the analyses, and node support was calculated using 1000 bootstrap replications for both the MP and NJ trees. MP analyses employed the heuristic nearneighbor-interchange search method. For the LWS phylogenies, sequences under the following accession numbers were used: Poecilia reticulata EU329431, EU329445, EU329453 and EU329457; Poecilia bifurca EU329460, EU329461, EU329465 and EU329466; Poecilia parae EU329468, EU329470 and EU329471; Poecilia picta EU329473, EU329474, EU329476 and EU329477; Xiphophorus pygmaeus EU329478, EU329479 and EU329481; Oryzias latipes AB223051 and AB223052; Gasterosteus aculeatus BT027981; Takifugu rubripes AY598942; Tetraodon nigroviridis AY598943; Danio rerio AB087803 and AB087804; Xenopus tropicalis BC135755; and Xiphophorus helleri LWS sequences described in this study. Additionally, for construction of the SWS2 trees, we used the following sequences: Anableps anableps FJ711152 and FJ711151; Lucania goodei AY296737 and AY296736; Poecilia reticulata FJ711159 and DQ234860; Oryzias latipes AB223056 and AB223057; Metriaclima zebra AF247114 and AF317118; Oreochromis niloticus AF247120 and AF247116; Trematomus loennbergii AY771356; Cottus gobio AJ430489; Gasterosteus aculeatus BT027452; Hippoglossus hippoglossus AF316497; Pseudopleuronectes americanus AY631038; Takifugu rupripes AY598947; Tetraodon nigroviridis AY598948; Girella punctata AB158256; Gadus morhua AF385822; Oncorhynchus mykiss AF425075; Salmo salar AY214134; Danio rerio AB087809; Cyprinus carpio AB113668; Carassius auratus L11864; Xenopus tropicalis AY177405; as well as the Xiphophorus helleri SWS2 sequences characterized here.

\section{Teleost gene synteny and LCR candidate search}

We used web based Genomicus synteny browser [68] and Ensembl genome browsers [34] to assess the synteny between regions sequenced for $X$. helleri in this study and five other teleost genomes for which data were available (Ensembl assembly versions: medakaHdrR; stickleback-BROAD S1; Tetraodon-TETRAODON 8.0; fugu-FUGU 4.0; zebrafish-Zv8). Only genes annotated in these assembly versions were considered for our synteny comparison. Likewise, for the $L W S$ regulatory region candidate search, we used available sequence from each of the species listed above, as well as from Pundamilia pundamilia [4], a species of African cichlid. Intergenic sequences between SWS2 and the closest $L W S$ gene from all seven species were analyzed using multipipmaker [69] to locate regions of high sequence conservation (See Additional file 1 for sequences used in the analysis). Identification of potential transcription factor binding sites was done by eye from aligned sequences, using previously identified consensus binding sites for transcription factors with known involvement in opsin gene regulation [70-72].

\section{Results and Discussion}

Xiphophorus helleri opsin genomic organization and gene structure

Using a single 60 bp $L W S$ specific probe designed from previously reported $L W S$ sequences [6-8] we detected 
16 BAC clones positive for $L W S$ opsin genes from the $X$. helleri BAC library, VMRC-27 [43]. HindIII fingerprint analysis clustered the $16 \mathrm{BAC}$ clones into two separate fingerprint contigs containing 11 (Contig I) and five clones (Contig II), respectively. The segregation of BAC clones into two separate contigs was expected due to the fact that one of the three previously reported LWS genes in Xiphophorus pygmaeus is thought to be a retrotransposed gene (S180r) [8]. Because retrogenes are usually inserted into regions that are not linked to their ancestral copies [73] we predicted that one of the two fingerprint contigs represented the retrogene locus. To test this hypothesis we used $L W S$ locus specific primers (Additional file 1) to screen each of the $16 \mathrm{BAC}$ clones by PCR for the presence of the LWS retrogene, S180r, and the two other previously reported $L W S$ opsins in Xiphophorus, S180 and P180 [8]. All of the Contig II BAC clones tested positive only for the LWS retrogene, S180r, whereas each of the Contig I BAC clones were positive for either one or both of the other two LWS genes but not for S180r. Subsequently, because LWS genes are linked to $S W S 2$ opsins in other teleosts, we tested Contig I BACs for the presence of SWS2A and $S W S 2 B$ opsins using consensus primers designed from guppy (DQ234860), Lucania goodei (AY296736, AY296737), medaka (AB223056, AB223057), and cichlid (AF247120, AF247116) $S W S 2 A$ and $S W S 2 B$ opsin sequences. A single BAC clone from Contig I (VMRC27-186P13) that was positive for all SWS2 and $L W S$ opsin PCR primer sets and a single BAC clone from Contig II (VMRC27-80H16) were chosen for shotgun library construction and sequencing, from which we identified complete sequences of four LWS (S180-1; S180-2; P180;S180r) and two SWS2 (SWS2A, SWS2B) opsin genes (Fig. 1).

BAC clone VMRC27-186P13 (GenBank accession: GQ999832) assembled into two ordered sequence contigs $109 \mathrm{~kb}$ and $55 \mathrm{~kb}$ in length, and contained a linked gene cluster of three LWS (S180-1; S180-2; P180) and two SWS2 opsins (SWS2A; SWS2B; Fig. 1A). The two highly similar $S 180$ genes with $99 \%$ shared coding sequence identity flank the $P 180$ gene on either side. S180-2 and P180 are positioned on the chromosome in a tail-to-tail orientation, 3,718 bp apart, an organization previously described in Poecilia [8]. S180-1 is located 5,400 bp upstream of $P 180$. The two SWS2 copies are tightly linked $1,893 \mathrm{bp}$ apart, and reside $8,563 \mathrm{bp}$ upstream of S180-1. S180 and P180 subtypes have been described in the genus Poecilia, in X. pygmaeus [8] and in the anablepid, Jenysia onca [74]. It should also be mentioned that sequence in the 3' portion of the $S 180 \mathrm{\gamma}$ subtype in another anablepid, Anableps anableps, shares high sequence similarity with $P 180$ genes observed in Poecilia species [75]. The A. anableps S180 $\gamma$ is the likely result of gene conversion [75]. Given that the P180 subtype has been identified in J. onca, and at least partially in A. anableps, the duplication event that produced this locus most likely precedes the split of Poeciliidae and Anablepidae [74,75]. Moreover, the tail-to-tail organization of X. helleri S180-2 and P180 is identical to that of $S 180$ and $P 180$ genes described in $P$. reticulata, $P$. parae, P. picta, and P. bifurca [8]. This provides strong evidence that these genes are orthologs. However, the organization has not been characterized for the $S 180$ and $P 180$ subtypes described in anablepids $[74,75]$ nor those described in X. pygamaeus [8]. It is therefore unclear whether the $S 180$ genes described in these species are orthologous to the X. helleri S180-2 locus or S180-1 locus. The genomic organization of the SWS2A and $S W S 2 B$ genes has not been described in any other poeciliid to date; however, $S W S 2$ genes are also linked to $L W S$ genes in many other species (see below).

The second sequenced BAC clone, VMRC27-80H16 (GenBank accession: GQ999833), assembled into a single $162 \mathrm{~kb}$ sequence contig (Fig. 1B) and revealed the presence of a fourth $L W S$ opsin, an ortholog of the S180r gene previously described in Poecilia, Xiphophorus and Lucania $[7,8]$ and two species from the family Anablepidae [74,75]. It is presumed to be the result of a retrotransposition event as no introns have been observed in PCR products generated from genomic DNA of any of the genera mentioned above $[8,74,75]$. Until our study only exons II through VI of the S180r retroposed gene had been described, and based on the lack of introns it was postulated that this was a completely intronless gene. Here we provide a more complete description of this gene, including a first exon that is homologous to exon I of the other LWS genes described here and a single intron. Analyses of human retroduplicates have shown that some retrogenes acquire introns de novo following their insertion back into the genome [76-78]. However, in this case the S180r exon I and intron I structure and organization are homologous to that observed in X. helleri S180-1 and S180-2. This homology indicates the $S 180 r$ intron was likely not acquired post duplication, but instead suggests that reverse transcription and genome reinsertion occurred before the first exon of the ancestral LWS mRNA transcript had been spliced out. However, the former hypothesis of post duplication intron gain cannot be completely discounted.

This study provides the first examination of the genomic location of the S180r gene in relation to other $L W S$ gene family members. During the process of retrotransposition, retrogenes can be inserted into regions of the genome unlinked to their ancestral copy and in many cases are inserted into exons or introns of other genes [73]. In line with this trend, we have shown that S180r 


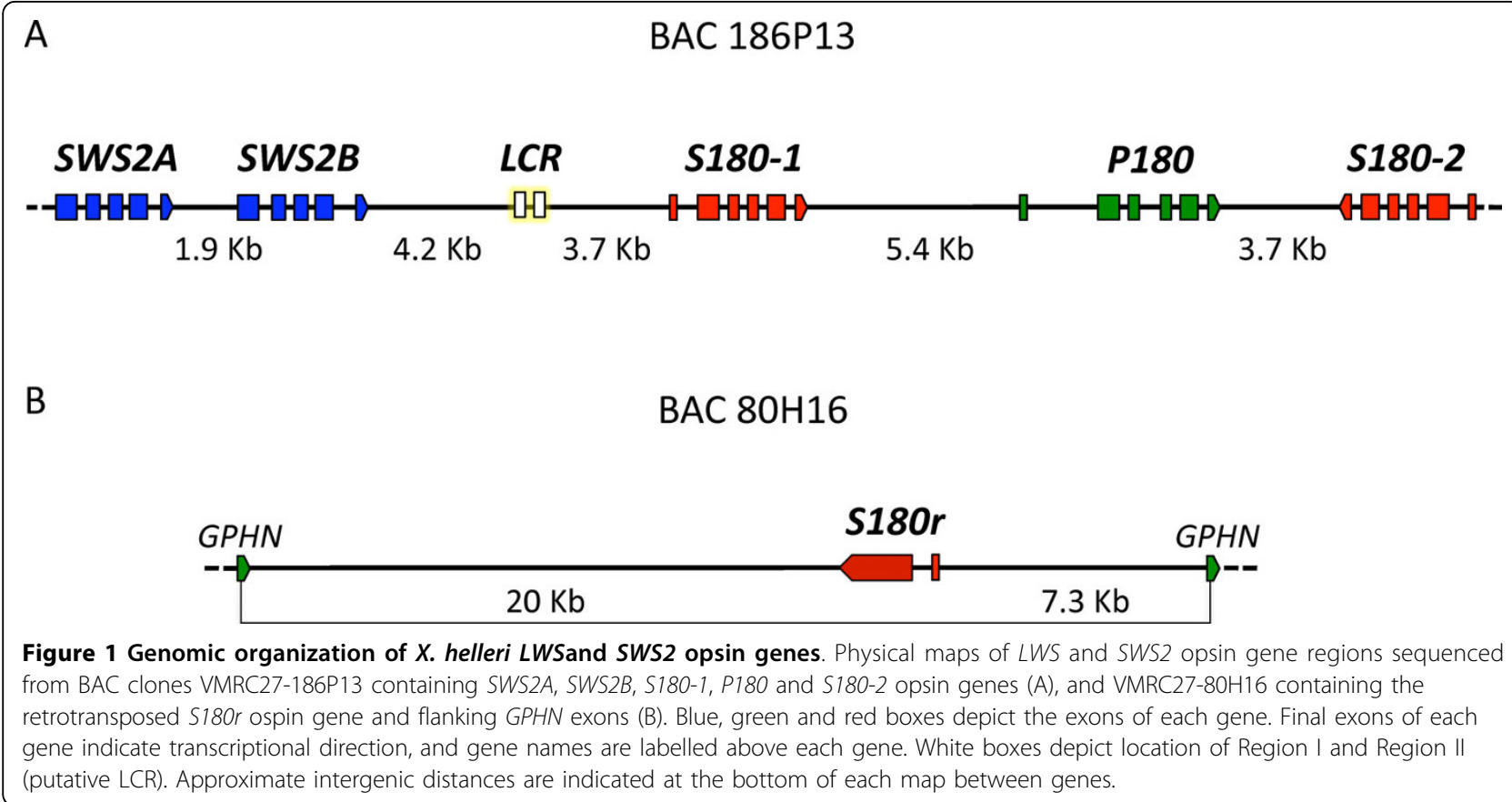

has been inserted into an intron of an unrelated gene, identified here as gephyrin (GPHN). Additionally, because $G P H N$ and surrounding genes are not linked to the LWS/SWS2 gene cluster in other teleosts (see below), it is likely that $S 180 \mathrm{r}$ is not linked to the other $X$. helleri $L W S$ genes identified in this study, further supporting the hypothesis that S180r is the product of retrotransposition.

LWS opsins S180-1, S180-2, and P180 contain six exons and five introns (Fig. 2A). This feature is shared across vertebrate $M W S / L W S$ opsins [9]. Fig. 2A shows that exon length is highly conserved across these three LWS subtypes. However, introns I and III of P180 have undergone increases in size, making them larger than introns I and III of the S180-1 and S180-2 copies. The S180r gene contains only a single intron. The first exon and intron are similar in size to those of the other $L W S$ $S 180$ genes, and exon II of S180r corresponds to exons II through VI of the other three $L W S$ genes (Fig. 2A). Of the four LWS opsins, S180-1 and S180-2 are most similar, differing by only one amino acid caused by a single non-synonymous nucleotide change. However, the genes encoding S180-1 and S180-2 are different within the 5' and 3' untranslated regions (UTRs). Also shown in Fig. 2A are the "five-site" haplotypes for each LWS subtype. The "five-sites" rule has been well established in the vertebrate opsin literature, and refers to five key amino acid sites in the opsin protein that contribute to significant changes in spectral sensitivity [59]. The three S180 opsins share the same "five-site" haplotype (SHYTA), and are predicted to absorb light maximally at the same wavelength, whereas the five site haplotype of $P 180$ (PHFAA) is different from that observed in the S180 subtypes and is expected to have a different $\lambda_{\max }$. It should be noted that S180r differs from the other two S180 proteins outside the five key sites, sharing only $89 \%$ amino acid sequence identity. Weadick and Chang [7] reported amino acid changes specific to the P. reticulata S180r protein compared to the other guppy $L W S$ subtypes (H247R, A248D, V249I, S256C, K261N, E263Q and $\mathrm{R} 264 \mathrm{~K})$, and suggested that this opsin may have increased transducin binding ability, as changes at these sites in bovine rhodopsin-although not the exact changes mentioned above in all instances-are known to be involved in transducin binding [79]. The same changes reported for the guppy $180 r$ protein are also observed in the $X$. helleri S180r protein. Additionally, S180-1 and S180-2 also contain a lysine at amino acid site 264 , in place of an arginine, which is found in all non S180r LWS opsins reported in the guppy, as well as the $P 180$ opsin reported here for $X$. helleri.

$X$. helleri SWS $2 A$ and $S W S 2 B$ genes have five exons and four introns (Fig. 2B). A similar structure is found in SWS2, SWS1 and RH2 genes described in other vertebrates [9]. Exon length in the two SWS2 genes reported here is identical for exons I through IV, and differs by only $3 \mathrm{bp}$ in exon V. However, as is the case with the LWS opsins described in this study, there are many differences in the length of introns between the two genes, particularly in introns I and IV. All introns of the $L W S$ and $S W S 2$ opsins reported here contain standard (5' GT-AG 3') splice sites. 


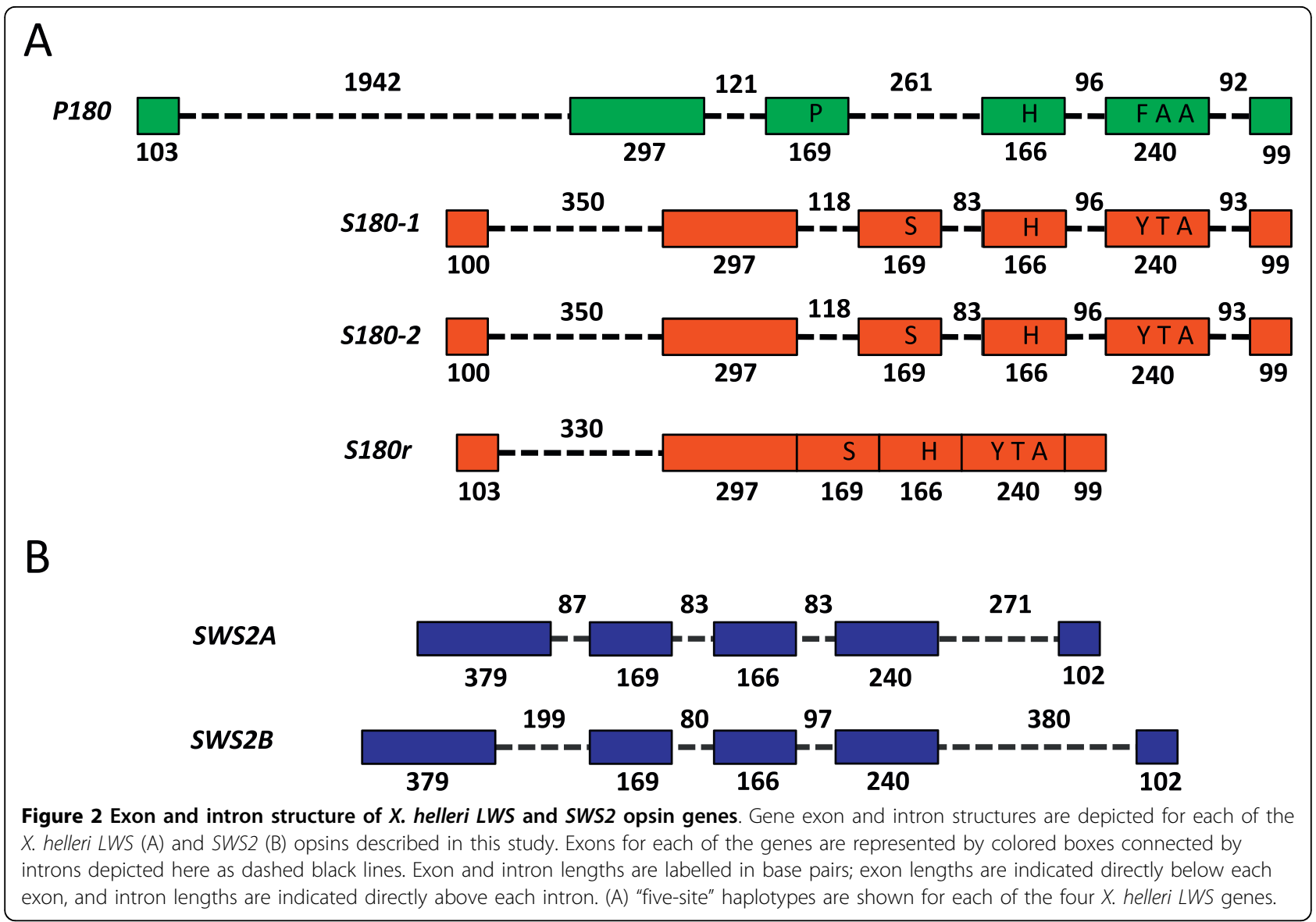

Phylogenetic analysis of LWS and SWS2 sequences

Fig. 3 shows a Neighbor Joining (NJ) tree representing LWS opsin evolution in Xiphophorus and Poecilia. As only partial gene transcripts have been submitted for multiple species and subtypes, sequence lengths used for the analysis range from $621 \mathrm{bp}$ to $1,083 \mathrm{bp}$. Included in the phylogeny are all Poecilia and Xiphophorus LWS sequences reported to date, as well as sequences for zebrafish, medaka, stickleback, Tetraodon and fugu, because these species were used in synteny analyses (see below). Multiple independent lineage-specific gene duplications are shown in the tree for medaka, zebrafish and within poeciliids. However, it should be noted that the duplication event leading to S180r predates the split of Fundulidae, Anablepidae and Poeciliidae [8,74,75]. Additionally, at least two of the other $L W S$ genes described in poeciliids and anablepids likely share a common origin $[74,75]$. LWS duplications have also been identified in other teleosts, including the blind cavefish, Astyanax fasciatus [80] and Girella punctata [81]. Consistent with Ward et al. [8], the poeciliid $L W S$ opsins form three clades. Each of the $X$. helleri LWS opsins characterized in this study cluster with sequences from $X$. pygmaeus and Poecilia speciesbased on opsin subtype, and one interpretation of the analysis (Fig. 3) is that the $X$. helleri $S 180-1$ and $S 180-2$ represent a gene duplication specific to Xiphophorus.

It has also been suggested that the $A 180$ haplotype, which has so far only been observed in Poecilia species, is the product of a genus-specific duplication followed by partial gene conversion with the P180 locus [8]. However, as previously discussed by Ward et al. [8], the Poecilia $A 180$ sequences share high sequence similarity with the $S 180$ genes and do not form a single monophyletic group, but rather are interspersed within the clade of $S 180$ sequences. Our discovery of a second $S 180$ locus in Xiphophorus suggests an alternative hypothesis to that of two genus-specific duplications (one in Poecilia, producing A180 locus, and one in Xiphophrous, producing the second $S 180$ ); it is possible that $X$. helleri S180-1 and Poecilia A180 are orthologous loci that predate the Xiphophorus and Poecilia divergence. Under this hypothesis Poecilia A180 is the result of gene diversification, as well as possible gene conversion with the P180 locus following the divergence of $A 180$ and $S 180$. Additionally, homogenization of $X$. helleri S180-1 and S180-2 genes may have occurred after the divergence of Poecilia and Xiphophorus. In support of this there is 


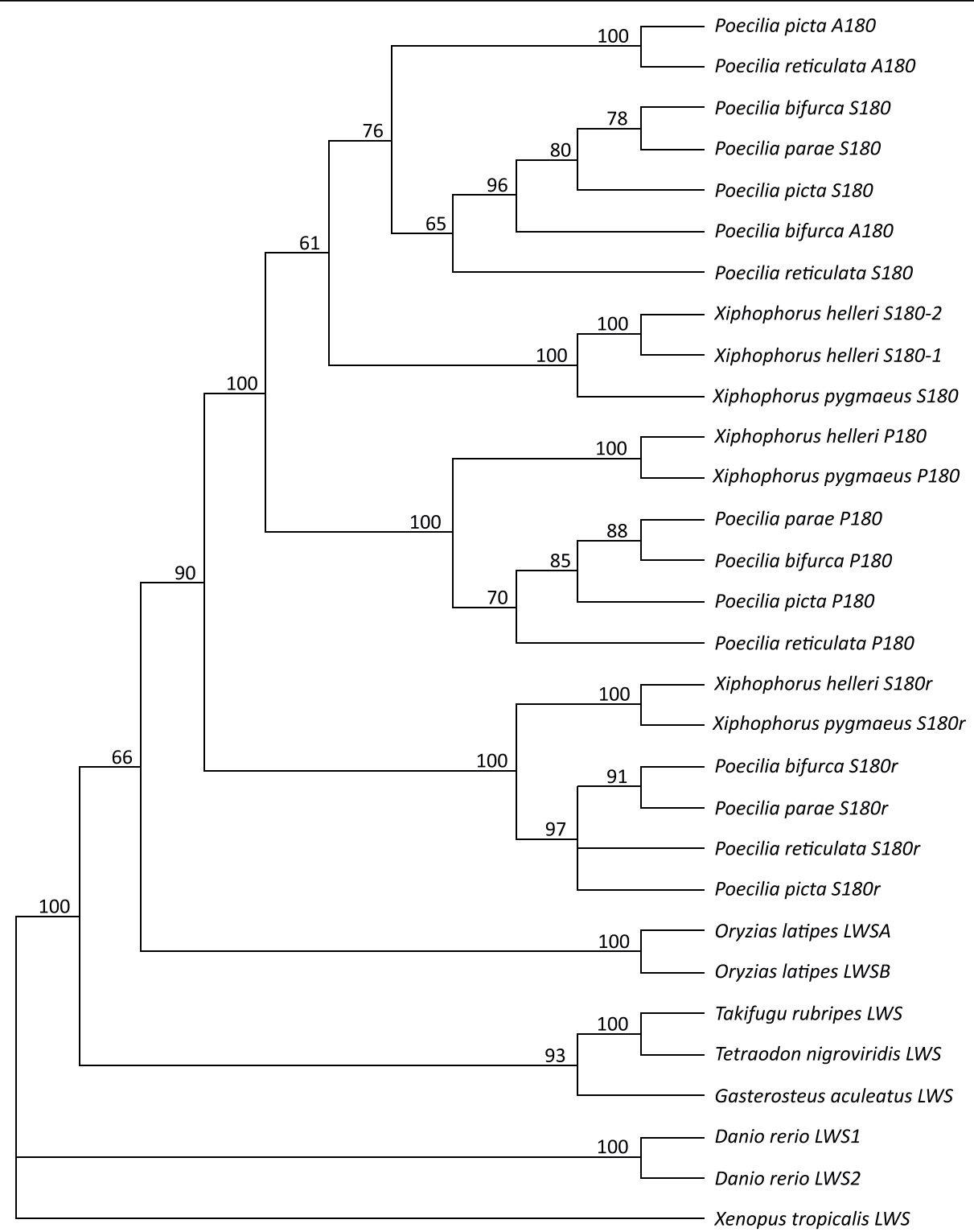

Figure 3 Neighbor Joining phylogeny of Xiphophorus and Poecilia LWS opsin genes. NJ tree was reconstructed using the GTR $+1+G$ model of evolution. Within the tree, values from 1000 bootstrap reiterations are labelled at the nodes. Nodes with values less than $50 \%$ were collapsed. LWS sequences from the five teleost species used for gene synteny comparisons in this study were also included. The Xenopus tropicalis LWS gene sequence was used as the outgroup. Species and gene names are labelled at each of the tips in the phylogeny.

ample evidence for gene conversion from both poeciliids [8] and the closely related anablepids [74,75]. However, data are needed from a wider range of species before the effects of duplication, divergence and gene conversion can be rigorously evaluated.

For the SWS2 NJ tree (Fig. 4) we used SWS2 coding sequences $412 \mathrm{bp}$ to $1,089 \mathrm{bp}$ in length from 20 species representing a broad range of the teleostei lineage. Unlike the LWS gene phylogeny, which is dominated by multiple recent duplication events, the SWS2 phylogeny depicts a much older origin for the X. helleri SWS2 opsin duplicates at the base of Acanthopterygii. This finding is consistent with previously reported phylogenetic results $[33,82,83]$. It has also been previously noted that multiple species within Acanthopterygii are represented in the phylogeny by a single SWS2 gene (Fig. 4), representing either gene loss or incomplete descriptions of the opsin gene repertoires in those species [33]. Interestingly, species outside of Acanthopterygii with only single genes have evolved $S W S 2$ genes to match the spectral sensitivity ranges of either the $S W S 2 A$ or $S W S 2 B$ genes observed in other species [11]. In the case 


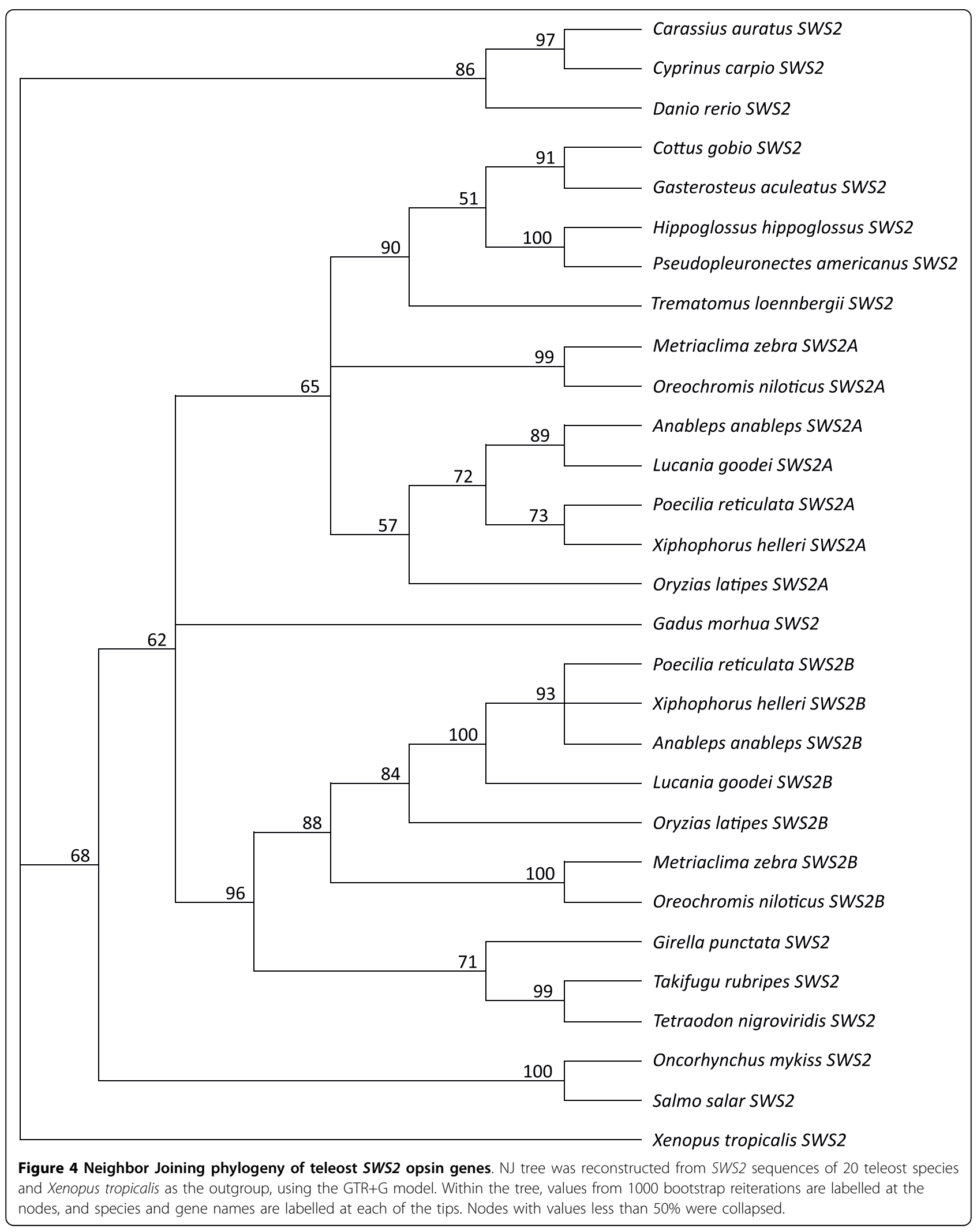


of $X$. helleri, both $S W S 2 A$ and $S W S 2 B$ cluster in the tree with their respective orthologs in $P$. reticulata, $A$. anableps and L. goodei. MP trees were also constructed for sequences depicted in the LWS and SWS2 NJ trees and show only minor differences in topology (see Additional file 2).

\section{$X$. helleri and teleost synteny}

The results of gene synteny analyses between annotated $X$. helleri BAC sequences and the corresponding regions of five other teleost species are shown in Fig. 5A and 5B. We identified eight complete gene sequences in the BAC VMRC27-80H16, including the S180r retrotransposed LWS opsin gene (Fig. 5A). S180r was not found at this locus in any of the other five teleost genomes used for comparison in this study. The order and orientation of the remaining genes MPP5, ATP6vId, EIF2S1, RBM25, $H S P 90$ and $S L C 35 B 2$ are conserved in medaka and zebrafish, except that the zebrafish also has two genes (ENSDARG00000068789 and ENSDARG00000079963) not observed in the other species. In stickleback the conserved block of genes mentioned above is disrupted by the translocation of genes RBM25, HSP90 and SLC35B2. A smaller synteny block, including MPP5, ATP6vId, EIF2S1, RBM25 and HSP90, is also conserved in fugu, and in Tetraodon. In both of these species SLC35B2 is located at a separate, unlinked locus.

The second region analyzed (Fig. 5B) includes 14 genes annotated from BAC VMRC27-186P13. Most of the variation between species in this region is associated with $L W S$ and SWS2 opsin gene copy number. Shown in Fig. 5B, X. helleri has two SWS2 genes and three $L W S$ genes. Medaka also has two SWS2 copies that are orthologous to the $S W S 2 A$ and $S W S 2 B$ described here in $X$. helleri. Each of the other four species has only a single SWS2 copy. Additionally, whereas stickleback, Tetraodon and fugu only have a single LWS gene, medaka and zebrafish have two. It should be pointed out that these second copies are predicted products of lineage-specific duplication events (Fig. 3). Despite these differences, the synteny block boxed in blue (Fig. 5B) is highly conserved across all of the teleosts analyzed here. This gene organization has also been described in monotremes and most likely represents the ancestral SWS2/LWS gene organization found in the most recent common ancestor of mammals, fish, birds and reptiles $[38,84]$.

\section{Retinal cone pigment characterization and opsin gene expression}

Assessing the spectral absorbance properties of opsin proteins can be achieved by making comparisons between MSP and molecular opsin sequence data [85] or by visual pigment reconstitution [86]. Moreover, given the extensive amount of effort spent characterizing the effect of amino acid substitutions at key sites in vertebrate $M W S / L W S$ opsins, broad scale spectral sensitivities can be roughly inferred and assigned to a given opsin protein based on its five site haplotype. This has been attempted for the LWS opsins so far identified in the guppy and related species [6-8]. However, in Poeciliidae, no study has yet made direct associations between MSP data and opsin sequences from individuals of the same population and strain.

We found that $X$. helleri adult retinas exhibit six separate cone and rod classes defined by differences in maximal spectral sensitivities (Fig. 6). All of the visual pigments fit the typical A1 chromophore pigment-curve and the average $\lambda_{\max }$ values observed are as follows; UV cone class $\left(\lambda_{\max }=365 \mathrm{~nm}\right.$; Fig. $\left.6 \mathrm{~A}\right)$, violet cone class $\left(\lambda_{\max }=405 \mathrm{~nm}\right.$; Fig. 6B), blue cone class $\left(\lambda_{\max }=459\right.$ nm; Fig. $6 \mathrm{C})$, green cone class $\left(\lambda_{\max }=534 \mathrm{~nm}\right.$; Fig. $\left.6 \mathrm{D}\right)$, yellow cone class $\left(\lambda_{\max }=568\right.$; Fig. $\left.6 \mathrm{E}\right)$ and a rod class $\left(\lambda_{\max }=499 \mathrm{~nm} ;\right.$ Fig. 6F $)$. Maximum absorbance averages for the green and yellow cone classes are similar to those described in other poeciliids. The molly, Poecilia mexicana, has two LWS cone classes with average $\lambda_{\max }$ values of $536 \mathrm{~nm}$ and $563 \mathrm{~nm}$ [87], whereas the guppy retina exhibits one to three with $\lambda_{\max }$ values of $533 \mathrm{~nm}, 548 \mathrm{~nm}$ and $572 \mathrm{~nm}$ [31]. Although, it should be noted that the $548 \mathrm{~nm}$ cone class is proposed to be the result of a mixture of the $533 \mathrm{~nm}$ and $577 \mathrm{~nm}$ cone classes [31]. Using cDNA synthesized from whole eye total RNA of adult male and female $X$. helleri (Rio Sarabia Strain), products representing each of the $L W S$ (S180-1, S180-2, P180, S180r) and SWS2 (SWS2B) opsin subtypes were successfully amplified by PCR, and partial sequences for RH2-1, RH2-2, SWS1 and RH1 opsins were also amplified and sequenced (see Additional File 1 for PCR primers). Partial sequences for $R H 2-1, R H 2-2$, SWS1 and RH1 opsins have been deposited under the following GenBank accession numbers (GU454732, GU454733, GU454734, GU454735).

The four $X$. helleri LWS genes described here are grouped into two five-site haplotype classes (Fig. 2A). The $S 180$ subtype genes (S180-1, S180-2, S180r) share a common five-site haplotype (SHYTA) and are predicted to exhibit similar spectral sensitivities. This haplotype has also been identified in each of the $L W S$ duplicates of both killifish and medaka $[33,85]$. However, the killifish $L W S$ duplicates have a $\lambda_{\max }$ at approximately 573 $\mathrm{nm}$, whereas the two LWS copies found in medaka exhibit a lower $\lambda_{\max }$, near $560 \mathrm{~nm}[33,85]$. The human $L W S$ opsin, which has the SHYTA five site haplotype, also has a $\lambda_{\max }$ of $560 \mathrm{~nm}[59,88,89]$. Our MSP data show two peaks in the range predicted to be associated with LWS spectral sensitivity, one at $534 \mathrm{~nm}$ and another at $568 \mathrm{~nm}$. The lower of these two values, $534 \mathrm{~nm}$, is near 


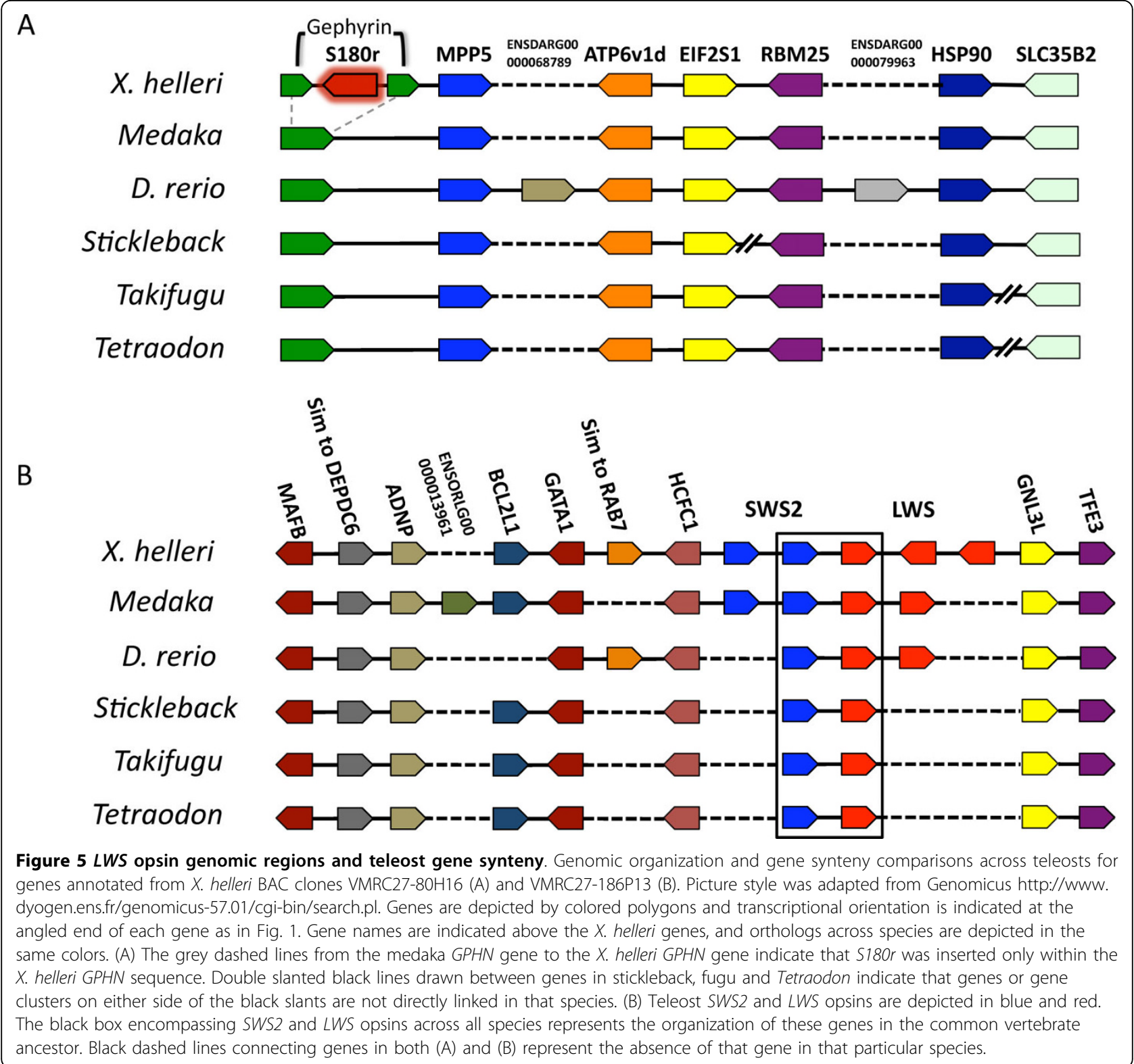

the assigned $\lambda_{\max }$ of the human $M W S$ protein (the human $M W S$ arose via duplication of the primate $L W S$ locus; ref 34), and one of the cavefish $L W S$ proteins [88-90]. Human MWS and cavefish LWS opsins both share the haplotype AFHAA while the $X$. helleri P180 protein (PFHAA) differs at only a single site. Taken together, these data allow us to conclude that the $X$. helleri peak observed here at $568 \mathrm{~nm}$ most likely corresponds to the $S 180$ subtypes. However, the fact that we were also able to amplify $R H 2$ subtypes from eye cDNA limits our ability to definitively assign the $534 \mathrm{~nm}$ cone to the LWS P180 gene, as RH2 opsins have also been shown to represent cone classes in this spectral range $[12,85]$.
We were unable to amplify $S W S 2 A$ from cDNA using two different sets of primers designed in $5^{\prime}$ and $3^{\prime}$ UTR sequence, and in exons III and IV (Additional File 1), although a nested PCR approach did result in $S W S 2 A$ amplification. MSP data from this study indicated the presence of a cone pigment class with an average $\lambda_{\max }$ of $459 \mathrm{~nm}$ (Fig. 6C), which is within the expected range of teleost SWS2A pigments [10,12,85,91]. However, RH2 opsin absorption spectra as low as $459 \mathrm{~nm}$ have also been observed in other teleosts. For example, the $R H 2-\mathrm{A}$ gene in medaka has a $\lambda_{\max }$ of $452 \mathrm{~nm}$ [33], and the zebrafish $R H 2-1$ gene has a $\lambda_{\max }$ of $467 \mathrm{~nm}$ [32]. Therefore, similar to the $534 \mathrm{~nm}$ cone discussed above, it is difficult to conclude which opsin protein is responsible for 


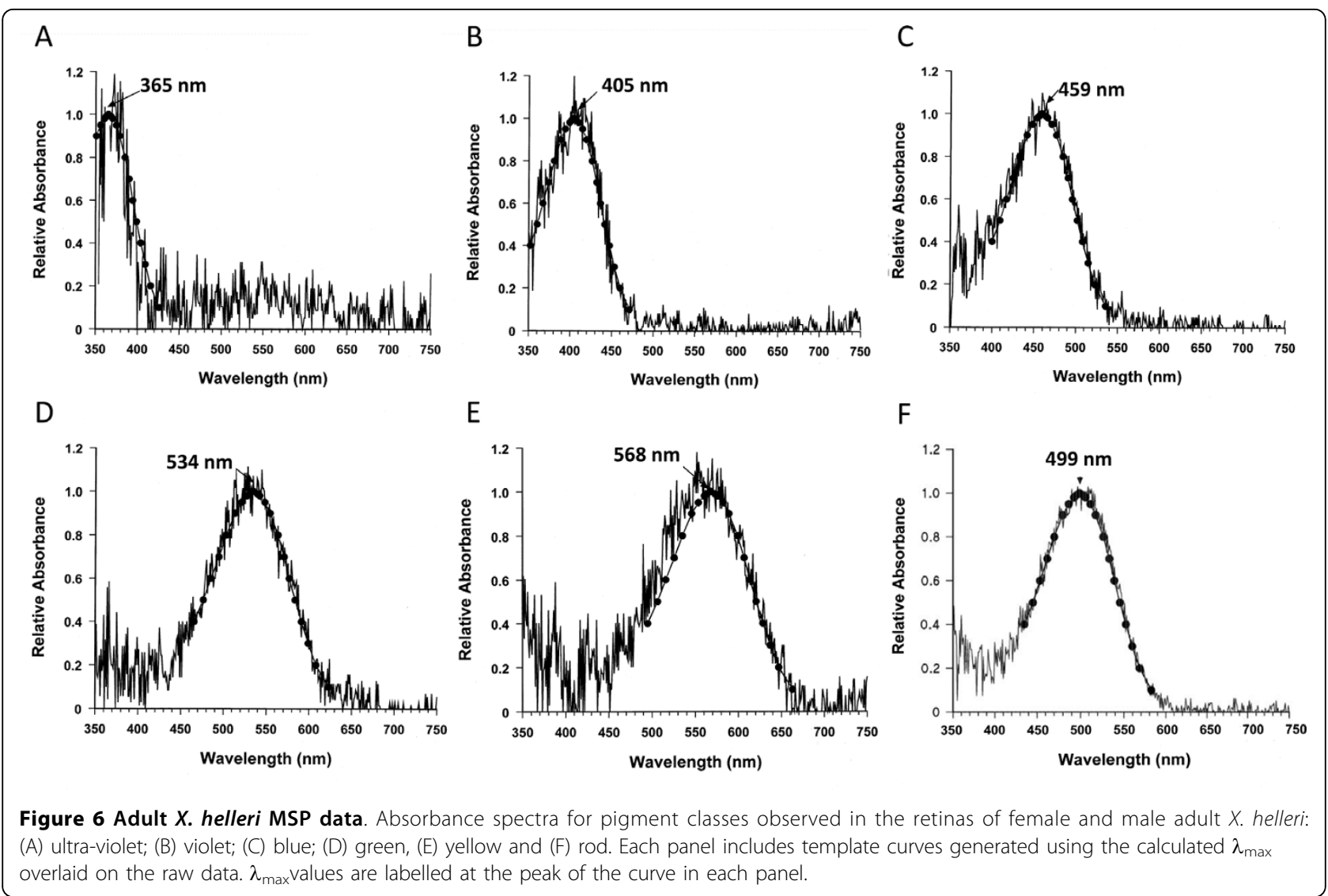

the $467 \mathrm{~nm}$ pigment class. In both of these instances a quantitative PCR approach seeking to ascertain differences in opsin gene expression levels could help clarify these discrepancies.

Compared to $S W S 2 A$ opsins, $S W S 2 B$ genes typically exhibit lower $\lambda_{\max }$ values between $405 \mathrm{~nm}$ and $425 \mathrm{~nm}$ [11]. We detected a violet cone class with a $\lambda_{\max }$ of 405 $\mathrm{nm}$, which is the cone pigment class most likely to correspond to the $X$. helleri $S W S 2 B$ gene. SWS2B opsins in both medaka and the killifish have absorption maxima of $405 \mathrm{~nm}[33,85,91]$. Lastly, the fifth cone class described in this study by MSP has a $\lambda_{\max }$ of $365 \mathrm{~nm}$, and most likely represents the SWS1 gene. Within teleosts, SWS1 opsin absorption maxima fall primarily within the ultra violet region of the light spectrum, unlike many other vertebrates, which have evolved SWS1 opsins sensitive to longer wavelengths $[10,11]$. One exception, however, is the scabbardfish SWS1 gene, which has evolved a $\lambda_{\max }$ of $423 \mathrm{~nm}$ [14].

We were also able to amplify PCR products for $G P H N$, suggesting that expression of this gene is not disrupted by the insertion of S180r. The insertion of S180r into GPHN raises interesting questions about the fate of retroduplicates. As mentioned above, retrogenes are typically reinserted at loci unlinked to their ancestral copies. Many examples have recently come to light that suggest retrogenes are able to travel with basic regulatory sequences acquired from their ancestral locus or "hijack" those of their neighboring genes once reinserted back into the genome [73]. It is unknown if the expression of this $L W S$ retrogene is facilitated by one of the two mechanisms above or an alternative one. Given that we were able to show expression of the GPHN gene, known to be expressed in the zebrafish retina [92], this provides an indication that the chromosomal region where S180r now resides is active in the eye of adult $X$. helleri, and may provide a starting point for asking questions about the mechanisms maintaining S180r expression. It should be noted that we were unable to amplify S180r from cDNA using primers designed within the predicted 5' UTR, suggesting that S180r could be a product of gene fusion. Fusion transcripts are sometimes observed in cases in which retrotransposed duplicates have been inserted into other genes [73]. Even though S180r and GPHN do not have the same transcriptional orientation, we tested for fusion transcripts of the two genes by attempting PCR with two different combinations of GPHN and S180r primers (Additional File 1), but no products were produced from either of the two combinations used. 
Candidate regulatory elements conserved in SWS2/LWS intergenic sequence: implications for opsin expression Similar to the $X$. helleri LWS genes described in this study, human $L W S / M W S$ opsin genes are linked and organized in a tandem array [35]. Retinal specific expression of the human $L W S / M W S$ genes is regulated by a shared LCR [35-42]. This region has been identified across mammalian taxa $[38,39,93]$, and regions analogous to the mammalian $L W S$ LCR have been identified for other opsin gene classes as well [94-96].

Using multipipmaker [69] we identified two highly conserved candidate opsin regulatory regions within the intergenic sequence between $S W S 2$ and $L W S$ opsins in seven teleost species (Fig. 7A, 7B). The two regions, Region I and Region II, are separated by approximately 300-450 bp of sequence (depending on the species) with low phylogenetic conservation. The locations of these regions are indicated in Fig. 7.

Region I, which is located farther upstream of $L W S$ opsins than Region II in all species surveyed, is a highly conserved $90 \mathrm{bp}$ stretch containing two conserved blocks of sequence (24 bp long and 29 bp long; Fig. 7A) with $100 \%$ shared nucleotide similarity across all seven teleost species. Included within this region are several sequences (Fig. 7A) showing similarity to previously described hormone response element (HRE) half sites [70]. HREs bind nuclear hormone receptors that act as ligand-induced transcription factors following the binding of an appropriate steroid, hormone or vitamin, activating or suppressing gene transcription [97]. Many hormone receptors are known to be involved in the proper development of cone photoreceptor cells [98-101]. In mice, liganded thyroid hormone receptor $\beta 2(\mathrm{TR} \beta 2)$ is known to activate expression of $M W S$ opsins, while both TR $\beta 2$ and retinoid $\mathrm{X}$ receptor $\gamma$ (RXR $\gamma$ ) are known to suppress $S W S$ opsin expression [98-101]. It has also been shown in juvenile salmonids that thyroid hormone exposure can induce opsin expressional changes in the retina from $S W S 1$ subtypes to SWS2 subtypes [102]. The preferred HRE half site sequence of TRs and many other non-steroid receptors is based on the sequence PuG [G/T]TCA [70]. However, it should be noted that the sequence of the HRE half site used is dependent on the receptor it is binding, and these sites could be expected to show considerable variation from reported consensus sequences [97]. HRE

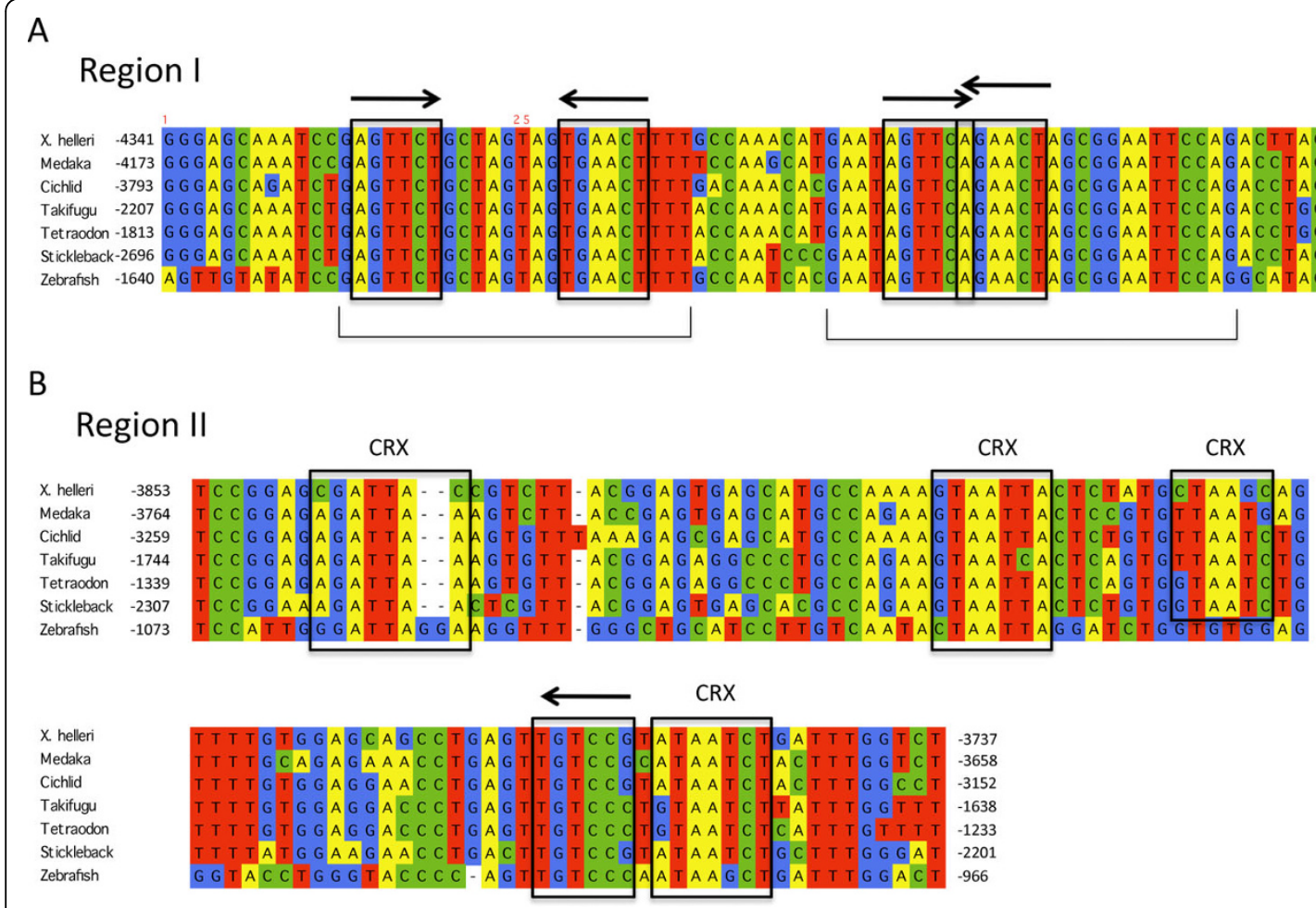

Figure 7 Potential regulatory regions identified as conserved regions upstream of $L W S$ across seven teleost species, including $\boldsymbol{X}$. helleri. (A) Region I: $90 \mathrm{bp}$ of conserved sequence. Black brackets indicate regions with 100 percent shared sequence identity across the seven teleosts shown. Two putative hormone response element (HRE) half-site arrangements are boxed in black. (B) Region II: 106-107 bp of conserved sequence. Four putative CRX binding sites and a single HRE half-site are boxed in black. Black arrows in (A) and (B) indicate sequence direction of HRE half-sites. Bp locations of both regions in relation to the start codon of the LWS gene are indicated for each species at the left and right of the alignments. 
half-sites typically occur in duplicate and can be arranged as palindromic, direct, inverted or everted repeats [97]. In Region I we identified two candidate HRE palindromic repeat arrangements (Fig. 7A). Halfsites of one of the palindromic repeats are spaced by 8 nucleotides. The other palindromic arrangement contains half-sites with overlapping sequences. In addition to teleosts, we were able to identify Region I upstream of LWS opsin genes in the frog, Xenopus tropicalis, and lizard, Anolis carolinensis (Additional File 3), each of which has physically linked SWS2 and LWS opsin genes.

The second region identified, Region II, is 106-107 bp in length and compared to region I is only moderately conserved across teleosts. The zebrafish Region II is most divergent from the other species (Fig. 7B), but this is expected considering that the zebrafish is distantly related to the other species analyzed here [103]. Although this region shows weaker conservation across species, it contains a single HRE half-site, similar to those in Region I, and four potential cone-rod-homeobox (CRX) transcription factor binding sites based on previously identified consensus sequences [71,72]. The presence of CRX binding sites is a feature shared with other opsin regulatory regions: the mammalian $L W S$ opsin LCR [40-42], the mammalian rod expression region [94], zebrafish $R H 2$ opsin LCR [95] and zebrafish SWS2 cis-acting regulatory elements [96]. CRX is part of the OTX family of transcription factors and is known to be involved in expression of photoreceptor specific genes $[71,72,99]$. For example, photoreceptor specific genes, which are partially regulated by CRX, show low retinal expression in mice mutants homozygous for a CRX mutation [104]. Also, deletions involving the human $M W S / L W S$ LCR, which contains multiple putative CRX binding sites, have been linked to a visual defect known as blue cone monochromacy in which no $M W S$ or $L W S$ opsins are expressed in the retina [40,41]. The conservation of these non-coding regions across many species alludes to a possible functional role. Wakefield et al. [38] postulate that the opsin LCR found in monotremes, which is homologous to that described in other mammals, controls the expression of both the LWS and SWS2 opsin genes. This could also be true for the putative elements we have uncovered for teleosts. However, further work is needed to assess the role that these regions may play in controlling opsin expression and photoreceptor development, whether separately, or in concert.

Elucidating the function of regulatory elements at this locus in conjunction with what we now know about poeciliid $L W S$ opsin organization from this study could prove to be fundamental to our understanding of how LWS opsins have influenced sexual selection and speciation in these fish. In the human retina, the expression of
LWS cones exceeds that of MWS cones, and it has been suggested that opsin gene regulatory sequence variation, opsin gene proximity to the LCR, and the three-dimensional chromatin structure of the $L W S / M W S$ locus may explain these differences [42,105-107]. As in the human $L W S / M W S$ array, zebrafish $R H 2$ opsin gene expression is also dependent on an LCR. It is unknown to what extent the LCR influences spatial and temporal differences in zebrafish $R H 2$ expression $[95,108]$, however, proximity to the LCR has been shown experimentally to influence expression levels using artificial expression constructs [95]. Spatial and temporal expression differences have also been observed for zebrafish $L W S$ opsins [32,108]. Ward et al. [8], using RT-qPCR, showed that the guppy $A 180 L W S$ gene is expressed at much higher levels compared to the other three $L W S$ subtypes. Given that the guppy $A 180$ locus is potentially orthologous to the $5180-1$ locus described here for $X$. helleri, it is possible that this gene could also be the closest gene to the LCR in the Poecilia LWS array. If this were in fact true, then the proximity of the $A 180$ locus in relation to the LCR could be the mechanism driving higher expression levels of the $A 180$ gene observed in the guppy. Whether high relative $A 180$ expression is a trend across Poecilia species remains to be investigated. Indeed, MSP data have shown considerable variation in retinal long wavelength sensitivity within a single guppy population $[30,31]$, suggesting that relative opsin expression levels are not necessarily fixed between individuals of the same population or species. Differences in long wavelength sensitivity have also been found using MSP between species and populations of mollies, which are also in the genus Poecilia [87]. However, it is unknown if the differences in visual potential observed in guppies and mollies correspond to variation in female preferences for male coloration patterns [30,31,87]. It will undoubtedly be important to examine to what extent genomic organization, gene copy number variation and opsin promoter sequence polymorphisms affect opsin expressional differences, and in turn how this may contribute to population and species divergence in mate choice in poeciliids, a classic model for the study of evolution by sexual selection.

\section{Conclusions}

We have characterized the genomic organization of four $L W S$ and two SWS2 opsin genes in the green swordtail fish, Xiphophorus helleri. Three of the LWS genes (S180-1, S180-2, P180) reside in tandem and are linked to two SWS2 opsin genes (SWS2A, SWS2B), whereas the retrotransposed S180r LWS gene is located at a separate unlinked locus. S180-2, P180 and S180r have each been described previously in other species. However, it is unclear whether the S180-1 opsin is orthologous to the 
Poecilia A180 gene, one of the three $S 180$ genes described in anablepids, or is the result of a Xiphophorus- or X. helleri-specific duplication event. Further descriptions of the genomic organization of LWS opsin genes in a broader range of species will provide a more definitive understanding of the evolutionary relationships between these genes. Eleven opsins, including the four LWS and two SWS2 opsin genes described at the genomic level, are expressed in female and male adult retinas, contributing to six retinal cone and rod classes assessed by MSP. To date it is unclear exactly what regulatory mechanisms control the expression of $L W S$ and SWS2 opsins in X. helleri or any teleost, although temporal, spatial and relative expressional differences have been observed in several other species. We have identified two candidate $L W S$ opsin regulatory regions. Experiments assessing the function of these regions are currently underway.

\section{Additional file 1: PCR primers, and sequences used for}

Multipipmaker analysis. Top Left: A list of tools and databases utilized

by the GRASP gene annotation pipeline. Top Right: PCR primers used for

LWS opsin-positive $X$. helleri BAC clones, and for PCR screening of

$X$. helleri adult female and male whole eye CDNA. PCR primers from other

studies are referenced in "References" column. PCR results and

sequencing notes for CDNA PCR screening are also listed in their

respective columns. Bottom: Sequences from six teleost species used in addition to those described in this study for $X$. helleri for multipipmaker analyses. For Pundamilia pundamilia a GenBank accession number is provided. For all sequences used from one of the Ensembl genome browsers, assembly versions, chromosome/scaffold numbers and base pair positions are listed [100-108]

\section{Additional file 2: LWS and SWS2 Maximum Parsimony phylogenies}

MP trees for LWS (left) and SWS2 (right) genes, constructed from sequences and alignments used for NJ trees in Figs. 3 and 4. Gene sequences for Xenopus tropicalis SWS2 and LWS genes were used as outgroups. Within the tree, values from 1000 bootstrap reiterations are labelled at the nodes, and species and gene names are labelled at each of the tips.

Additional file 3: Alignment of Region I in Xenopus tropicalis and Anolis carolinensis. Region I: 90-94 bp of conserved sequence. Black brackets indicate regions with 100 percent shared sequence identity across the species shown. Two putative hormone response element (HRE) half-site arrangements are boxed in black, and black arrows indicate sequence direction of HRE half-sites. Bp locations of both regions in relation to the start codon of the LWS gene are indicated at the left and right of the alignments for each species.

\footnotetext{
Acknowledgements

The authors would like to thank the members of Dr. Davidson's lab at Simon Fraser University, particularly Kim Johnstone and Evelyn Davidson, for help with wet lab techniques. We also would like to thank the lab of Dr. Taylor at the University of Victoria for many useful discussions, and additional thanks to Greg Owens, Jeff Joy and Ben Sandkam for editing the manuscript. Additionally, we thank Richard Moore and Jacqueline Schein at the BC Genome Sciences Centre for overseeing BAC sequencing and BAC fingerprinting projects. Fish for this project were supplied by the Xiphophorus Genetic Stock Center, and BAC clone library filters and BAC clones were supplied by CHORI. This work was funded by the Natural Sciences and Engineering Research Council of Canada.
}

\section{Author details}

${ }^{1}$ Department of Biological Sciences, Simon Fraser University, Burnaby, BC, Canada. ${ }^{2}$ Department of Molecular Biology and Biochemistry, Simon Fraser University, Burnaby, BC, Canada. ${ }^{3}$ Department of Biomedical Sciences, Cornell University, Ithaca, NY, USA

\section{Authors' contributions}

CTW carried out molecular wet lab experiments and bioinformatics with assistance and training from KPL and WSD. EL conducted MSP. FB is credited with project design and development, and in conjunction with WSD, was responsible for general project oversight. CTW wrote the manuscript with editing assistance from KPL, EL, WSD and FB. All authors read and approved the final manuscript.

Received: 2 October 2009 Accepted: 30 March 2010

Published: 30 March 2010

\section{References}

1. Fitzpatrick MJ, Ben-Shahar Y, Smid HM, Vet LEM, Robinson GE, Sokolowski MB: Candidate genes for behavioural ecology. Trends Ecol Evol 2005, 20:96-104.

2. Andersson M, Simmons LW: Sexual selection and mate choice. Trends Ecol Evol 2006, 21:296-302.

3. Chenoweth SF, Blows MW: Dissecting the complex genetic basis of mate choice. Nat Rev Genet 2006, 7:681-692.

4. Seehausen $\mathrm{O}$, Terai $\mathrm{Y}$, Magalhaes IS, Carleton $\mathrm{KL}$, Mrosso HD, Miyagi $\mathrm{R}$, Sluijs van der I, Schneider MV, Maan ME, Tachida H, Imai H, Okada N: Speciation through sensory drive in cichlid fish. Nature 2008, 455:620-626.

5. Carleton $\mathrm{KL}$ : Cichlid fish visual systems: mechanisms of spectral tuning. Integr Zool 2009, 4:74-86.

6. Hoffmann M, Tripathi N, Henz SR, Lindholm AK, Weigel D, Breden F, Dreyer C: Opsin gene duplication and diversification in the guppy, a model for sexual selection. Proc R Soc Lond B 2007, 274:33-42.

7. Weadick CJ, Chang BSW: Long-wavelength sensitive visual pigments of the guppy (Poecilia reticulata): six opsins expressed in a single individual. BMC Evol Biol 2007, 7(Suppl 1):S11.

8. Ward MN, Churcher AM, Dick KJ, Laver CRJ, Owens GL, Polack MD, Ward PR, Breden F, Taylor JS: The molecular basis of color vision in colorful fish: Four Long Wave-Sensitive (LWS) opsins in guppies (Poecilia reticulata) are defined by amino acid substitutions at key functional sites. BMC Evol Biol 2008, 8:210.

9. Yokoyama S: Molecular Evolution of Vertebrate Visual Pigments. Prog Retin Eye Res 2000, 19:385-419.

10. Bowmaker JK: Evolution of vertebrate visual pigments. Vision Res 2008, 48:2022-2041.

11. Bowmaker JK, Loew ER: Vision in Fish. The Senses: A Comprehensive Reference Boston: ElsevierMasland RH, Albright T 2008, 1:53-76.

12. Parry JWL, Carleton KL, Spady T, Carboo A, Hunt DM, Bowmaker JK: Mix and match color vision: tuning spectral sensitivity by differential opsin gene expression in Lake Malawi cichlids. Curr Biol 2005, 15:1734-1739.

13. Bowmaker JK, Govardovskii VI, Shukolyukov SA, Zueva LV, Hunt DM, Sideleva VG, Smirnova OG: Visual pigments and the photic environment: the cottoid fish of Lake Baikal. Vision Res 1996, 34:591-605.

14. Tada T, Altun A, Yokoyama S: Evolutionary replacement of UV vision by violet vision in fish. Proc Natl Acad Sci USA 2009, 106:17457-17462.

15. Kodric-Brown A: Female preference and sexual selection for male coloration in the guppy (Poecilia reticulata). Behav Ecol Sociobiol 1985, 17:199-205.

16. Bakker TCM: Positive genetic correlation between female preference and preferred male ornament in sticklebacks. Nature 1993, 363:255-257.

17. Seehausen O, van Alphen JJM: The effect of male coloration on female mate choice in closely related Lake Victoria cichlids (Haplochromis nyererei complex). Sociobiology 1998, 42:1-8.

18. Bisazza A, Pilastro A: Variation of female preference for male coloration in the eastern mosquitofish Gambusia holbrooki. Behav Genet 2000, 30:207.

19. Endler JA: Natural and sexual selection on color patterns in poeciliid fishes. Environ Biol Fishes 1983, 9:173-190.

20. Houde AE: Sex, Color, and Mate Choice in Guppies. Princeton: Princeton University Press 1997. 
21. Basolo AL: Female preference for male sword length in the green swordtail, Xiphophorus helleri (Pisces: Poeciliidae). Anim Behav 1990, 40:332-338.

22. Rosenthal GG, Wagner WE Jr, Ryan MJ: Secondary reduction of preference for the sword ornament in the pygmy swordtail Xiphophorus nigrensis (Pisces: Poeciliidae). Anim Behav 2002, 63:37-45.

23. Wong BBM, Rosenthal GG: Female disdain for swords in a swordtail fish Am Nat 2006, 167:136-140.

24. Houde AE: Mate choice based upon naturally occurring color-pattern variation in a guppy population. Evolution 1987, 41:1-10.

25. Cummings ME, Rosenthal GG, Ryan MJ: A private ultraviolet channel in visual communication. Proc R Soc Lond B Biol Sci 2003, 270:897-904.

26. Kingston JJ, Rosenthal GG, Ryan MJ: The role of sexual selection in maintaining a colour polymorphism in the pygmy swordtail, Xiphophorus pygmaeus. Anim Behav 2003, 65:735-743.

27. Breden F, Stoner $\mathrm{G}$ : Male predation risk determines female preference in the Trinidad guppy. Nature 1987, 329:831-833.

28. Houde $A E$, Endler JA: Correlated evolution of female mating preferences and male color patterns in the guppy Poecilia reticulata. Science 1990, 248:1405-1408.

29. Endler JA, Houde AE: Geographic variation in female preferences for male traits in Poecilia reticulata. Evolution 1995, 49:456-468.

30. Archer SN, Endler JA, Lythgoe JN, Partridge JC: Visual pigment polymorphism in the guppy, Poecilia reticulata. Vision Res 1987, 27:1243-1252

31. Archer $S N$, Lythgoe JN: The visual pigment basis for cone polymorphism in the guppy, Poecilia reticulata. Vision Res 1990, 30:225-230.

32. Chinen A, Hamaoka T, Yamada Y, Kawamura S: Gene duplication and spectral diversification of cone visual pigments of zebrafish. Genetics 2003, 163:663-675

33. Matsumoto $Y$, Fukamachi S, Mitani H, Kawamura S: Functional characterization of visual opsin repertoire in Medaka (Oryzias latipes). Gene 2006, 371:268-278.

34. Hubbard TJP, Aken BL, Ayling S, Ballester B, Beal K, Bragin E, Brent S, Chen Y, Clapham P, Clarke L, Coates G, Fairley S, Fitzgerald S, FernandezBanet J, Gordon L, Graf S, Haider S, Hammond M, Holland R, Howe K, Jenkinson A, Johnson N, Kahari A, Keefe D, Keenan S, Kinsella R, Kokocinski F, Kulesha E, Lawson D, Longden I, Megy K, Meidl P, Overduin B, Parker A, Pritchard B, Rios D, Schuster M, Slater G, Smedley D, Spooner W, Spudich G, Trevanion S, Vilella A, Vogel J, White S, Wilder S, Zadissa A, Birney E, Cunningham F, Curwen V, Durbin R, Fernandez-Suarez XM, Herrero J, Kasprzyk A, Proctor G, Smith J, Searle S, Flicek P: Ensembl 2009. Nucleic Acids Res 2009, 37:D690-D697.

35. Vollrath TD, Nathans J, Davis RW: Tandem array of human visual pigment genes at Xq28. Science 1988, 240:1669-1672.

36. Dulai KS, von Dornum M, Mollon JD, Hunt DM: The evolution of trichromatic color vision by opsin gene duplication in New World and Old World primates. Genome Res 1999, 9:629-638.

37. Davies WL, Carvalho LS, Cowing JA, Beazley LD, Hunt DM, Arrese CA: Visual pigments of the platypus: A novel route to mammalian colour vision. Curr Biol 2007, 17:R161-R163.

38. Wakefield MJ, Anderson M, Chang E, Wei KJ, Kaul R, Graves JA, Grützner F, Deeb SS: Cone visual pigments of monotremes: Filling the phylogenetic gap. Vis Neurosci 2008, 25:257-264.

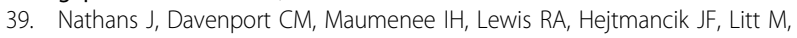
Lovrien E, Weleber R, Bachynski B, Zwas F, Klingaman R, Fishman G: Molecular-genetics of human blue cone monochromacy. Science 1989, 245:831-838

40. Wang Y, Macke JP, Merbs SL, Zack DJ, Klaunberg B, Bennett J, Gearhart J, Nathans J: A locus control region adjacent to the human red and green visual pigment genes. Neuron 1992, 9:429-440.

41. Winderickx J, Battisti L, Motulsky AG, Deeb SS: Selective expression of human X-chromosome-linked green opsin genes. Proc Natl Acad Sci USA 1992, 89:9710-9714.

42. Smallwood PM, Wang Y, Nathans J: Role of a locus control region in the mutually exclusive expression of human red and green cone pigment genes. Proc Natl Acad Sci USA 2002, 99:1008-1011.

43. Walter RB, Ju Z, Martinez A, Amemiya C, Samollow PB: Genomic resources for Xiphophorus research. Zebrafish 2006, 3:11-22.

44. Johnstone KA, Lubieniecki KP, Chow W, Phillips RB, Koop BF, Davidson WS: Genomic organization and characterization of two vomeronasal 1 receptor-like genes (ora1 and ora2) in Atlantic salmon Salmo salar. Mar Genomics 2008, 1:23-31.

45. Schein J, Kucaba T, Sekhon M, Smailus D, Waterston R, Marra M: Highthroughput BAC fingerprinting. Methods in Molecular Biology (Clifton, NJ) 2004, 255:143-156.

46. Ewing B, Green P: Base calling of automated sequencer traces using phred. II. Error probabilities. Genome Res 1998, 8:186-194.

47. Ewing B, Hillier L, Wendl M, Green P: Base calling of automated sequencer traces using phred. I. Accuracy assessment. Genome Res 1998, 8:175-185.

48. Gordon D, Abajian C, Green P: Consed: a graphical tool for sequence finishing. Genome Res 1998, 8:195-202.

49. The GRASP Annotation Pipeline. [http://grasp.mbb.sfu.ca/]

50. Altschul S, Madden T, Schaffer A, Zhang J, Zhang Z, Miller W, Lipman D: Gapped BLAST and PSI-BLAST: a new generation of protein database search programs. Nucleic Acids Res 1997, 25:3389-3402.

51. Kent W: BLAT-the BLAST-like alignment tool. Genome Res 2002, 12:656-664.

52. Ning Z, Cox AJ, Mullikin JC: SSAHA: a fast search method for large DNA databases. Genome Res 2001, 11:1725-1729.

53. The GENSCAN Web Server at MIT. [http://genes.mit.edu/GENSCAN.html].

54. Krogh A, Larsson B, von Heijne G, Sonnhammer EL: Predicting transmembrane protein topology with a hidden Markov model: application to complete genomes. Journal of Molecular Biology 2001, 3:567-580

55. RepeatMasker Open-3.0. 1996-2004. [http://www.repeatmasker.org].

56. Pruitt K, Tatusova T, Maglott D: NCBI reference sequences (RefSeq): a curated non-redundant sequence database of genomes, transcripts and proteins. Nucleic Acids Res 2007, 35:D61-65.

57. Suzek B, Huang H, McGarvey P, Mazumder R, Wu C: UniRef: comprehensive and non-redundant UniProt reference clusters. Bioinformatics (Oxford) 2007, 23:1282-1288.

58. Marchler-Bauer A, Anderson JB, Chitsaz F, Derbyshire MK, DeWeese-Scott C, Fong JH, Geer LY, Geer RC, Gonzales NR, Gwadz M, He S, Hurwitz DI, Jackson JD, Ke Z, Lanczycki CJ, Liebert CA, Liu C, Lu F, Lu S, Marchler GH, Mullokandov M, Song JS, Tasneem A, Thanki N, Yamashita RA, Zhang D, Zhang N, Bryant SH: CDD: specific functional annotation with the Conserved Domain Database. Nucleic Acids Res 2009, 37:D205-210.

59. Yokoyama S, Radlwimmer FB: The "five-sites" rule and the evolution of red and green color vision in mammals. Mol Biol Evol 1998, 15:560-567.

60. Loew ER: A third, ultraviolet-sensitive, visual pigment in the Tokay Gecko (Gekko gecko). Vision Res 1994, 34:1427-1431.

61. Press WH, Flannery BP, Teukolsky SA, Vetterling WT: Numerical Recipes in Pascal. Cambridge: Cambridge University Press 1987.

62. MacNichol EFJ: A unifying presentation of photopigment spectra. Vision Res 1986, 26:1543-1556.

63. Lipitz LE, Cronin TW: Application of an invariant spectral form to the visual pigments of crustaceans: Implications regarding the binding of the chromophore. Vision Res 1988, 28:1083-1093.

64. Thompson JD, Higgins DG, Gibson TJ: Clustal-W-Improving the sensitivity of progressive multiple sequence alignment through sequence weighting, position-specific gap penalties and weight matrix choice. Nucleic Acids Res 1994, 22:4673-4680.

65. eBioX1.5.1. [http://www.ebioinformatics.org].

66. Swofford DL: PAUP*: Phylogenetic Analysis Using Parsimony.4.0b. Sunderland, Mass.: Sinauer Associated, Inc, 102002.

67. Milne I, Lindner D, Bayer M, Husmeier D, McGuire G, Marshall DF, Wright F: TOPALi v2: a rich graphical interface for evolutionary analyses of multiple alignments on HPC clusters and multi-core desktops. Bioinformatics (Oxford) 2009, 25:126-127.

68. Genomicus syteny browser-Dyogen Lab. [http://www.dyogen.ens.fr/lcgibin/search.pl].

69. Schwartz S, Zhang Z, Frazer KA, Smit A, Riemer C, Bouck J, Gibbs R, Hardison R, Miller W: PipMaker-A web server for aligning two genomic DNA sequences. Genome Res 2000, 10:577-586.

70. Kato S, Sasaki H, Suzawa M, Masushige S, Tora L, Chambon P, Gronemeyer H: Widely spaced, directly repeated PuGGTCA elements act as promiscuous enhancers for different classes of nuclear receptors. Molecular and Cellular Biology 1995, 15:5858-5867.

71. Chen SM, Wang QL, Nie ZQ, Sun H, Lennon G, Copeland NG, Gilbert DJ, Jenkins NA, Zack DJ: Crx, a novel Otx-like paired-homeodomain protein, 
binds to and transactivates photoreceptor cell-specific genes. Neuron 1997, 19:1017-1030.

72. Furukawa T, Morrow EM, Cepko CL: Crx, a novel otx-like homeobox gene, shows photoreceptor-specific expression and regulates photoreceptor differentiation. Cell 1997, 91:531-541.

73. Kaessmann $\mathrm{H}$, Vinckenbosch $\mathrm{N}$, Long M: RNA-based gene duplication: mechanistic and evolutionary insights. Nat Rev Genet 2008, 10:19-31.

74. Windsor DJ, Owens GL: The opsin repertoire of Jenynsia onca : a new perspective on gene duplication and divergence in livebearers. BMC Research Notes 2009, 2:159

75. Owens GL, Windsor DJ, Mui J, Taylor JS: A fish eye out of water: Ten visual opsins in the four-eyed fish, Anableps anableps. PLoS One 2009, 4 e5970.

76. Vinckenbosch N, Dupanloup I, Kaessmann H: Evolutionary fate of retroposed gene copies in the human genome. Proc Natl Acad Sci USA 2006, 103:3220-3225.

77. Baertsch R, Diekhans M, Kent WJ, Haussler D, Brosius J: Retrocopy contributions to the evolution of the human genome. BMC Genomics 2008, 9:466.

78. Fablet $\mathrm{M}$, Bueno $\mathrm{M}$, Potrzebowski L, Kaessmann H: Evolutionary origin and functions of retrogene introns. Mol Biol Evol 2009, 26:2147-2156.

79. Franke RR, Sakmar TP, Graham RM, Khorana HG: Structure and function in rhodopsin. Studies of the interaction between the rhodopsin cytoplasmic domain and transducin. Journal of Biological Chemistry 1992, 267:14767-14774.

80. Yokoyama R, Yokoyama S: Convergent evolution of the red- and greenlike visual pigment genes in fish, Astyanax fasciatus, and human. Proc Natl Acad Sci USA 1990, 87:9315-9318.

81. Miyazaki T, Yamauchi M, Takami M, Kohbara J: Putative ultravioletphotosensitivity in the retina of 1-year-old nibbler Girella punctata : Based on molecular and histological evidences. Fish Sci 2005, 71:159-167.

82. Neafsey DE, Hartl DL: Convergent loss of an anciently duplicated, functionally divergent $\mathrm{RH} 2$ opsin gene in the fugu and Tetraodon pufferfish lineages. Gene 2006, 370:125-125.

83. Spady TC, Parry JW, Robinson PR, Hunt DM, Bowmaker JK, Carleton KL: Evolution of the cichlid visual palette through ontogenetic subfunctionalization of the opsin gene arrays. Mol Biol Evol 2006, 23:1538-1547.

84. Kawamura S, Blow NS, Yokoyama S: Genetic analyses of visual pigments of the pigeon (Columba livia). Genetics 1999, 153:1839-1850.

85. Fuller RC, Carleton KL, Fadool JM, Spady TC, Travis J: Population variation in opsin expression in the bluefin killifish, Lucania goodei : a real-time PCR study. J Comp Physiol A Sens Neural Behav Physiol 2004, 190:147-154.

86. Yokoyama S: Phylogenetic analysis and experimental approaches to study color vision in vertebrates. Methods Enzymol 2000, 315:312-325.

87. Körner KE, Schlupp I, Plath M, Loew ER: Spectral sensitivity of mollies: comparing surface- and cave-dwelling Atlantic mollies, Poecilia mexicana. J Fish Biol 2006, 69:54-65.

88. Neitz M, Neitz J, Jacobs GH: Spectral tuning of pigments underlying redgreen color vision. Science 1991, 252:971-974.

89. Oprian DD, Asenjo AB, Lee N, Pelletier SL: Design, chemical synthesis, and expression of genes for the three human color vision pigments. Biochemistry 1991, 30:11367-11372.

90. Yokoyama S, Radlwimmer FB: The molecular genetics and evolution of red and green color vision in vertebrates. Genetics 2001, 158:1697-1710.

91. Yokoyama S, Takenaka N, Blow NS: A novel spectral tuning in the short wavelength-sensitive (SWS1 and SWS2) pigments of bluefin killifish (Lucania goodei). Gene 2007, 396:196-202.

92. Yazulla S, Studholme KM: Neurochemical anatomy of the zebrafish retina as determined by immunocytochemistry. Jour Neurocytol 2001, 30:551-592.

93. Hunt DM, Chan J, Carvalho LS, Hokoc JN, Ferguson MC, Arrese CA, Beazley LD: Cone visual pigments in two species of South American marsupials. Gene 2009, 433:50-55

94. Nie Z, Chen S, Kumar S, Zack DJ: RER, an evolutionarily conserved sequence upstream of the rhodopsin gene, has enhancer activity. Journal of Biological Chemistry 1996, 271:2667-2675.

95. Tsujimura T, Chinen A, Kawamura S: Identification of a locus control region for quadruplicated green-sensitive opsin genes in zebrafish. Proc Natl Acad Sci USA 2007, 104:12813-12818.
96. Takechi M, Seno S, Kawamura S: Identification of cis-acting elements repressing blue opsin expression in zebrafish UV cones and pineal cells. Journal of Biological Chemistry 2008, 283:31625-31632.

97. Aranda A, Pascual A: Nuclear hormone receptors and gene expression. Physiol Rev 2001, 81:1269-1304.

98. Ng L, Hurley JB, Dierks B, Srinivas M, Saltó C, Vennström B, Reh TA, Forrest $\mathrm{D}$ : A thyroid hormone receptor that is required for the development of green cone photoreceptors. Nat Genet 2001, 27:94-98

99. Yanagi Y, Takezawa S, Kato S: Distinct functions of photoreceptor cellspecific nuclear receptor, thyroid hormone receptor $\beta 2$ and $C R X$ in cone photoreceptor development. Invest Ophthalmol Vis Sci 2002, 43:3489-3494.

100. Roberts MR, Hendrickson A, McGuire CR, Reh TA: Retinoid X Receptor $\gamma$ is necessary to establish the S-opsin gradient in cone photoreceptors of the developing mouse retina. Invest Ophthalmol Vis Sci 2005, 46:2897-2904.

101. Roberts MR, Srinivas M, Forrest D, Morreale de Escobar G, Reh TA: Making the gradient: Thyroid hormone regulates cone opsin expression in the developing mouse retina. Proc Natl Acad Sci USA 2006, 103:6218-6223.

102. Cheng CL, Gan KJ, Flamarique IN: Thyroid hormone induces a timedependent opsin switch in the retina of salmonid fishes. Invest Ophthalmol Vis Sci 2009, 50:3024-3032

103. Volff J-N: Genome evolution and biodiversity in teleostfish. Heredity 2005, 94:280-294.

104. Furukawa T, Morrow EM, Li T, Davis FC, Cepko CL: Retinopathy and attenuated circadian entrainment in Crx-deficient mice. Nat Genet 1999, 23:466-470.

105. Neitz M, Balding SD, McMahon C, Sjoberg SA, Neitz J: Topography of longand middle-wavelength sensitive cone opsin gene expression in human and Old World monkey retina. Vis Neurosci 2006, 23:379-385.

106. McMahon C, Carroll J, Awua S, Neitz J, Neitz M: The L:M cone ratio in males of African descent with normal color vision. J Vision 2008, 8:1-9.

107. Gunther KL, Neitz J, Neitz M: Nucleotide polymorphisms upstream of the X-chromosome opsin gene array tune L:M cone ratio. Vis Neurosci 2008, 25:265-271.

108. Takechi M, Kawamura S: Temporal and spatial changes in the expression pattern of multiple red and green subtype opsin genes during zebrafish development. Journal of Experimental Biology 2005, 208:1337-1345.

doi:10.1186/1471-2148-10-87

Cite this article as: Watson et al:: Genomic organization of duplicated short wave-sensitive and long wave-sensitive opsin genes in the green swordtail, Xiphophorus helleri. BMC Evolutionary Biology 2010 10:87.

\section{Submit your next manuscript to BioMed Central and take full advantage of:}

- Convenient online submission

- Thorough peer review

- No space constraints or color figure charges

- Immediate publication on acceptance

- Inclusion in PubMed, CAS, Scopus and Google Scholar

- Research which is freely available for redistribution

Submit your manuscript at www.biomedcentral.com/submit
Biomed Central 